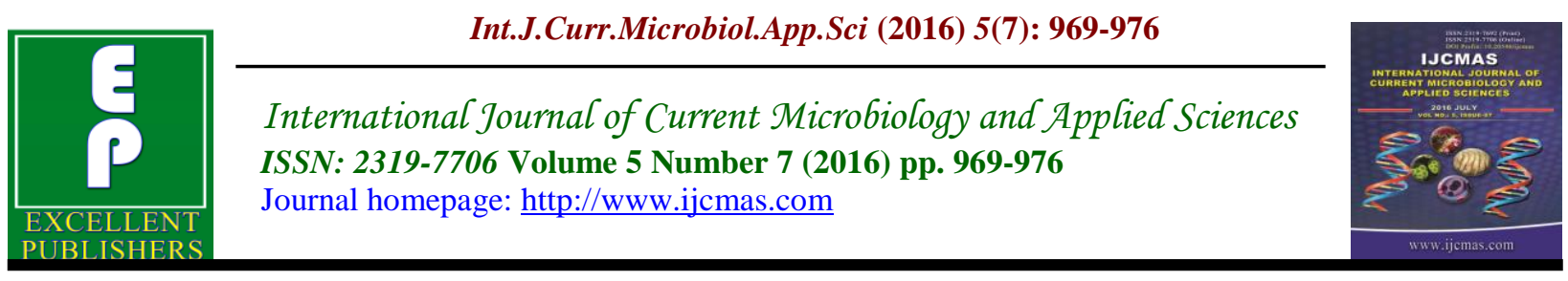

Original Research Article

http://dx.doi.org/10.20546/ijcmas.2016.507.109

\title{
Isolation and Screening of Fibrinolytic Enzymes producing Bacterium Strain from Soil Waste
}

\author{
S.M. Gopinath* and K. Lingappa \\ Department of Microbiology, Gulbarga University, Gulbarga, Karnataka, India \\ *Corresponding author
}

\begin{tabular}{|c|c|}
\hline & A B S T R A C T \\
\hline $\begin{array}{l}\text { K e y w o r d s } \\
\text { Fibrinolytic } \\
\text { enzymes, isolates, } \\
\text { fibrinolytic } \\
\text { activity, } \\
\text { caesinolytic and } \\
\text { gelatinolytic } \\
\text { activities. }\end{array}$ & \multirow{3}{*}{$\begin{array}{l}\text { Fibrinolytic enzymes help in dissolving the fibrin clots and they have the potential } \\
\text { use in the treatment of harmful cardiovascular diseases. High efficient fibrinolytic } \\
\text { enzymes are produced from the fibrinolytic microbes under extreme environmental } \\
\text { conditions. In the present work, microorganism strain that helps in the production } \\
\text { of fibrinolytic enzymes were isolated and screened from the soil waste. Five } \\
\text { isolates i.e., GSM-15, GSM - } 25 \text {, GSM - } 35 \text {, GSM - } 45 \text { and GSM }-55 \text { were subjected } \\
\text { to macroscopic characteristics The isolated organism was cultured in the sterile } \\
\text { media at } 37^{\circ} \mathrm{C} \text { for } 24 \text { hrs. The selected isolates were subjected to caseinolytic, } \\
\text { gelatinolytic and fibrinolytic activities was done. The fibrinolytic activity of } \\
\text { isolates GSM } 25 \text { and GSM } 55 \text { was higher than that of caesinolytic and gelatinolytic } \\
\text { activities. The selected isolates were tested with modified media compostition and } \\
\text { at different pH values. Isolate GSM-55 showed good enzyme productivity (13.1 } \\
\text { 2.6) U/ml at pH 8.0. Also the biochemical study indicated the isolate GSM } 55 \text { is } \\
\text { similar to that of Bacillus cereus with fibrinolytic function. }\end{array}$} \\
\hline Article Info & \\
\hline $\begin{array}{l}\text { ble Online: } \\
2016\end{array}$ & \\
\hline
\end{tabular}

\section{Introduction}

Fibrinolytic protease is well known as a sub class of protease, it has an ability to degrade fibrin (Fujita et al., 1993, 1995; Jeong et al., 2001, 2004; Leonardi et al., 2002; Sumi et al., 1995; Wong et al., 2004). Fibrin is normally formed from Fibrinogen by the action of Thrombin (EC 3.4.21.5). It is sliced by plasmin (EC 3.4.21.7) which is activated from plasminogen by tissue plasminogen activator (Voet et al., 1990). In balanced condition, fibrin clots are hydrolysed by plasmin to avoid thrombosis in blood vessels. However, in unbalanced condition, as a result of pathophysiological disorders, the clots are not hydrolysed. Deposition of fibrin in blood vessels normally increases thrombosis and other cardiovascular diseases such as high blood pressure, acute myocardial infarction, ischemic heart disease, valvular heart disease, peripheral vascular disease, arrhythmias, stroke etc. (Bode et al., 1996; Yoshinori et al., 2005).

Fibrinolytic agents are used to treat a wide variety of venous and arterial thromboembolic disorders; especially against acute myocardial infarction (Torrens 
et al., 1999). Based on working mechanism, thrombolytic agents are of two types, one is plasminogen activator which activates plasminogen into active plasmin to degrade fibrin and the other is plasmin like proteins which directly degrade fibrin (Koide et al., 1982). Despite widespread uses, thrombolytic agents are expensive. They exhibit low fibrin specificity and have undesired side effects such as gastrointestinal bleeding, resistance to repercussion and allergic reactions (Pautov et al., 1990). Therefore, continuous efforts have been focused in the search of safer and less expensive thrombolytic agents from diverse sources but one must respect biodiversity. Investigation of extracellular fibrinolytic enzymes is a essential due to their wide applications in clinical, pharmaceutical, food, and bioremediation process.

\section{Materials and Methods}

\section{Chemicals}

All chemicals and reagents used were of analytical grade obtained from Sigma USA.

\section{Determination of fibrinolytic protease activity}

The fibrinolytic protease activity was based on the hydrolytic power of the enzymes was determined by using the fibrin as substrate. Fibrinolytic protease activity was evaluated by the modified procedure of Greenberg (1957) using $2 \%$ bovine fibrin in $0.05 \mathrm{mM}$ phosphate buffer ( $\mathrm{pH}$ 8). $0.5 \mathrm{ml}$ fibrin solution with an equal volume of diluted enzyme solution was incubated for $10 \mathrm{~min}$ at $37^{\circ} \mathrm{C}$. The reaction was stopped by the addition of $10 \%$ cold Tri Chloroacetic Acid (TCA). The mixture was centrifuged at 3,000rpm for $10 \mathrm{~min}$ and to the supernatant $5 \mathrm{ml}$ of $0.44 \mathrm{M} \mathrm{Na}_{2} \mathrm{CO}_{3}$ was added, followed by the addition of $1 \mathrm{ml}$ of diluted Folin - ciocalteau reagent. The mixture was incubated for $30 \mathrm{~min}$ at $37^{\circ} \mathrm{C}$, the sample develops color change, and the intensity of colour change will be measured at $660 \mathrm{~nm}$ using Shimadzu UV-1700 (Japan) spectrophotometer against a blank reagent prepared without adding enzyme. Tyrosine is used as the reference standard.

\section{Estimation of extracellular protein}

Extracellular protein was estimated by Lowry method (Lowry et al., 1951). To the $1 \mathrm{ml}$ of dilute protein sample $(10-60 \mu \mathrm{g} / \mathrm{ml})$, $5 \mathrm{ml}$ alkaline working solution was added and mixed well which was incubated at $37^{\circ} \mathrm{C}$ for $10 \mathrm{~min}$. To the above mixture, $0.5 \mathrm{ml}$ Folin Ciocalteau reagent was added, mixed well and incubated at $37^{\circ} \mathrm{C}$ for $30 \mathrm{~min}$. The absorbence was measured at $680 \mathrm{~nm}$ in a spectrophotometer. The amount of protein present in the sample was calculated from the standard curve.

\section{Screening and isolation of fibrinolytic protease producing bacteria}

To isolate the potent fibrinolytic protease producing bactreria, soil samples were collected from various places in and around Bangalore, Karnataka, India. The soil samples were selected based on the varying characterisitics such as organic matter, particle size, colour of soil and geographical distribution. The samples were stored in sterile condition.

$1 \mathrm{~g}$ of the below samples was separately taken in a conical flask containing 100ml sterile water and the suspension was subjected to rotary shaker for 30 minutes. $1 \mathrm{ml}$ of the supernatant was serially diluted with sterile water and one $\mathrm{ml}$ of each of these dilutions was added to $20 \mathrm{ml}$ of sterile molten starch casein-agar medium maintained at $40^{\circ} \mathrm{C}$. 


\section{Samples}

\begin{tabular}{|l|l|l|}
\hline Sample & Source & Phsyical Characteristics \\
\hline GUG -I & $\begin{array}{l}\text { chicken centre, Shivaji Nagar, } \\
\text { Bangalore. }\end{array}$ & $\begin{array}{l}\text { brown colour sticky semi solid soil } \\
\text { sample }\end{array}$ \\
\hline GUG -II & $\begin{array}{l}\text { chicken centre, Tannery Road, } \\
\text { Bangalore }\end{array}$ & black colour sticky semi solid soil sample \\
\hline GUG -III & $\begin{array}{l}\text { slaughterhouse, nearby Tannery Road, } \\
\text { Bangalore }\end{array}$ & $\begin{array}{l}\text { brown colour sandy semi solid soil } \\
\text { sample }\end{array}$ \\
\hline GUG -IV & $\begin{array}{l}\text { dumping yard of chicken centre near } \\
\text { Tannery Road, Bangalore }\end{array}$ & $\begin{array}{l}\text { brown colour hard soil sample containing } \\
\text { the mixture of sand and clay }\end{array}$ \\
\hline GUG -V & $\begin{array}{l}\text { slaughterhouse, nearby Soldevanahalli, } \\
\text { Bangalore } \\
\text { bricken centre, Chikkabanavara, } \\
\text { Bangalore }\end{array}$ & brick red sticky soil sample \\
\hline GUG -VI & $\begin{array}{l}\text { dumping yard of chicken centre near } \\
\text { Devasandra lake, Bangalore }\end{array}$ & $\begin{array}{l}\text { red colour semi solid consisting of sand } \\
\text { and clay sample }\end{array}$ \\
\hline GUG -VIn -VII & $\begin{array}{l}\text { slaughterhouse, nearby Tin Factory, } \\
\text { Bangalore }\end{array}$ & red colour semi solid clay sample \\
\hline GUG -IX & $\begin{array}{l}\text { dumping yard of chicken centre near } \\
\text { Tin Factory, Bangalore }\end{array}$ & $\begin{array}{l}\text { black colour solid consisting of sand } \\
\text { and clay sample }\end{array}$ \\
\hline GUG -X & $\begin{array}{l}\text { dumping yard of fish market near } \\
\text { Yashwantpura Railway Station, } \\
\text { Bangalore }\end{array}$ & sand and clay sticky sample consisting of \\
\hline
\end{tabular}

It was mixed thoroughly and plated in $10 \mathrm{~cm}$ diameter sterile petridishes and incubated at $37^{\circ} \mathrm{C} . \quad 75 \mu \mathrm{g} / \mathrm{ml}$ of Flucanazole was incorporated to control the fungal contamination.

After $24 \mathrm{~h}$ of incubation, the bacteria colonies with clear hydrolyzed zones were transferred onto starch casein agar slants.

\section{Screening of isolates for proteolytic} activity

\section{Primary screening}

The selected isolates were initially screened for their proteolytic activities i.e. caseinolytic, gelatinolytic and fibrinolytic activities.

\section{Caseinolytic activity}

Caseinolytic activity of the isolates was evaluated using casein-agar plate technique

(Zerdani et al., 2004; Li et al., 2009; Gholamhossein et al., 2013). To the sterilized agar, $10 \%$ of pasteurized skimmed milk was added aseptically and the media was transferred into sterile petridish and kept aside for solidification. Then a loopful of each culture was streaked onto the medium, incubated at $37^{\circ} \mathrm{C}$ for $24 \mathrm{~h}$. The diameters of hydrolyzed zones around the colonies and the growth zones were measured. The ratio of hydrolysis zone/growth zone was calculated which gives a measure of the caseinolytic activities of the isolates. 


\section{Gelatinolytic activity}

$20 \mathrm{ml}$ of sterile nutrient gelatin agar medium (McLaughlin et al., 1996; Deshmukh et al., 1997; Tran et al., 2002; Shanmugasundaram et al., 2012) was poured in sterile petridishes and inoculated with a loop full of spores from $24 \mathrm{~h}$ old cultures and incubated at $37^{\circ} \mathrm{C}$ for 24h. The plates were flooded with mercuric chloride reagent (Williams et al., 1971). After treating with mercuric chloride$\mathrm{HCl}$ solution, the hydrolysis zone and growth zones were noted.

\section{Fibrinolytic protease activity}

To check the fibrinolytic protease activity, modified fibrin plate agar (Astrup et al., 1952; Kumaran et al., 2011) was poured in sterile petridishes and inoculated with a loop full of spores from $24 \mathrm{~h}$ old cultures and incubated at $37^{\circ} \mathrm{C}$ for $24 \mathrm{~h}$. The diameters of hydrolyzed zones around the colonies and the growth zones were measured. The ratio of hydrolysis zone/growth zone was calculated which gives a measure of the fibrinolytic protease activities of the isolates.

\section{Design of suitable basal medium}

Fibrinolytic protease production in shake flasks was checked using different media composition (table.2). $1 \mathrm{ml}$ of the cell suspension from the isolates was aseptically transferred into $250 \mathrm{ml}$ Erlenmeyer flasks containing $50 \mathrm{ml}$ each of sterile medium. The contents were incubated at $37^{\circ} \mathrm{C}$ for $24 \mathrm{~h}$ using rotary shaker at 70rpm. It is followed by centrifugation at 3000rpm for $10 \mathrm{~min}$ and the supernatant solution was tested for fibrinolytic protease activity by modified method of Greenberg 1957.

Determination of type of fibrinolytic protease produced by the isolates

To determine the whether the enzyme secreted by the isolate is of alkaline or acidic or neutral protease, fibrinolytic protease activity in the harvested broth was assayed by adding $0.5 \mathrm{ml}$ culture broth to $0.5 \mathrm{ml}$ of $2 \%$ fibrin solution. Further the activity was checked at different $\mathrm{pH}$ conditions using Citrate buffer ( $\mathrm{pH} 4.0$ ), Phosphate buffer (pH 7.0) and Carbonate buffer ( $\mathrm{pH}$ 8.0, 10.0) by dissolving the fibrin in respective buffers (Greenberg 1957).

\section{Results and Discussion}

From the ten soil samples collected 116 isolates were formed. Of the colonies formed, five isolates (Nos. 15, 25, 35, 45 and 55) were selected based on their macroscopic characteristics. They were sub cultured on starch casein agar media and subjected for secondary screening. They were designated as KLG-15, KLG -25, KLG -35, KLG -45 and KLG -55 . Extent of growth and the proteolytic activities of the selected isolates were checked and the results were presented in Table.1.

Study clearly indicated that isolates KLG 25 and KLG 55 are high fibrinolytic protease producers and they were further tested with medium IV and $\mathrm{V}$ for better fibrinolytic protease production.

\section{Design of suitable basal medium}

The composition of the medium IV and V were slightly changed in their fructose concentration and used for the production of fibrinolytic protease by isolates KLG 25 and KLG 55 to compare and design a suitable basal medium for efficient production. The results are presented in Table.4.

Determination of type of fibrinolytic protease produced by the isolates

Isolates KLG -25 and KLG -55 indicated 
high enzyme activity at $\mathrm{pH} 8$, indicating the enzyme is an alkaline protease. Further the isolate KLG-55 showed comparatively good enzyme productivity $(13.1 \pm 2.6) \mathrm{U} / \mathrm{ml}$.
Also, results of classification and identification clearly showed that the isolate KLG -55 is having similar characteristics as of Bacillus cereus.

Table.1 Growth pattern and proteolytic activities of selected isolates Secondary Screening

\begin{tabular}{|c|c|c|c|c|c|c|c|}
\hline \multirow[t]{2}{*}{ Sample No. } & \multirow{2}{*}{$\begin{array}{l}\text { Isolate } \\
\text { No. }\end{array}$} & \multicolumn{3}{|c|}{ Extent of Growth (24h) } & \multicolumn{3}{|c|}{ Proteolytic activity } \\
\hline & & CA & GA & FA & $\begin{array}{c}\text { Caseinolytic } \\
\text { activity }\end{array}$ & $\begin{array}{c}\text { Gelatinolytic } \\
\text { activity }\end{array}$ & $\begin{array}{c}\text { Fibrinolytic } \\
\text { protease } \\
\text { activity }\end{array}$ \\
\hline GUG -II & KLG 15 & ++ & + & ++ & 8.4 & 2.6 & 3.9 \\
\hline GUG -IV & KLG 25 & ++ & ++ & ++ & 7.8 & 5.6 & 6.9 \\
\hline \multirow[t]{2}{*}{$\mathrm{GUG}-\mathrm{V}$} & KLG 35 & ++ & + & ++ & 5.3 & 1.9 & 3.1 \\
\hline & KLG 45 & ++ & + & + & 5.8 & 2.6 & 2.3 \\
\hline GUG-VI & KLG 55 & ++ & - & ++ & 6.8 & 0 & 8.4 \\
\hline \multicolumn{5}{|c|}{$\begin{array}{l}\text { CA = Casein Agar Medium } \\
\text { GA = Gelatine Agar Medium } \\
\text { FA = Fibrin Agar Medium } \\
\text { Hydrolysed zone }(\mathrm{mm}) / \text { growth zone (mm) } \\
\quad \text { = Ratio }\end{array}$} & \multicolumn{3}{|c|}{$\begin{aligned}++ & =\text { Good growth } \\
++ & =\text { Moderate Growth } \\
- & =\text { No Growth }\end{aligned}$} \\
\hline
\end{tabular}

Fibrinolytic protease production was checked for the five isolates in shake flasks using different media composition (table.2). The results are presented in Table.3.

Table.2 Composition of different media for fibrinolytic protease production

\begin{tabular}{|c|l|}
\hline Medium No. & \multicolumn{1}{c|}{ Composition $(\mathbf{g} / \mathbf{1 0 0 m l})$} \\
\hline I & Glucose, $3.0 ;$ soyabean meal, $2.0 ; \mathrm{CaCl}_{2}, 0.04 ; \mathrm{MgCl}_{2}, 0.2$. \\
\hline II & Glucose $1.5 ;$ yeast extract, $0.5 ; \mathrm{CaCl}_{2}, 0.2$. \\
\hline III & Glucose, $0.1 ;$ yeast extract, $0.5 ;$ tryptone, 0.5. \\
\hline IV & Fructose, $1.0 ;$ fibrin; $0.2 ;$ peptone $1.0 ;$ salt solution $5 \mathrm{ml}^{*}$. \\
\hline V & Fructose, $0.5 ;$ fibrin; $0.2 ;$ peptone $1.0 ;$ salt solution $5 \mathrm{ml}^{*}$. \\
\hline VI & Fructose, $1.0 ;$ fibrin, $0.2 ;$ salt solution, $5 \mathrm{ml}^{*}$. \\
\hline VII & $\begin{array}{l}\text { Soluble starch, } 1 ; \mathrm{Casein}_{0}, 0.3 ; \mathrm{KNO}_{3} 0.2 ; \mathrm{K}_{2} \mathrm{HPO}_{4}, 0.2 ; \\
\text { MgSO }\end{array} 4,7 \mathrm{H}_{2} \mathrm{O} ; \mathrm{CaCO}_{3}, 0.002 ; \mathrm{FeSO}_{4}, 7 \mathrm{H}_{2} \mathrm{O} 2,0.001$. \\
\hline
\end{tabular}

* Salt Solution Composition (\%): $\mathrm{KNO}_{3}, 0.2 ; \mathrm{K}_{2} \mathrm{HPO}_{4}, 0.2 ; \mathrm{MgSO}_{4}, 7 \mathrm{H}_{2} \mathrm{O}, 0.005 ; \mathrm{CaCO}_{3}, 0.002 ; \mathrm{FeSO}_{4}, 7 \mathrm{H}_{2} \mathrm{O}$, 0.001 .

Table.3 Production of fibrinolytic protease $(\mathrm{U} / \mathrm{ml})$ by selected isolates in shake flask*

\begin{tabular}{|c|c|c|c|c|c|}
\hline $\begin{array}{c}\text { Medium } \\
\text { No. }\end{array}$ & $\begin{array}{c}\text { Isolate } \\
\text { KLG15 }\end{array}$ & $\begin{array}{c}\text { Isolate } \\
\text { KLG 25 }\end{array}$ & $\begin{array}{c}\text { Isolate } \\
\text { KLG 35 }\end{array}$ & $\begin{array}{c}\text { Isolate } \\
\text { KLG 45 }\end{array}$ & $\begin{array}{c}\text { Isolate } \\
\text { KLG 55 }\end{array}$ \\
\hline I & 3.7 & 2.5 & 4.2 & 2.6 & 4.0 \\
\hline II & 4.2 & 4.6 & 2.0 & 4.1 & 2.6 \\
\hline III & 5.1 & 4.8 & 2.8 & 1.2 & 4.2 \\
\hline IV & 1.2 & 7.6 & 1.8 & 1.3 & 8.6 \\
\hline V & 3.8 & 5.7 & 5.0 & 3.5 & 7.0 \\
\hline VI & 4.7 & 3.6 & 3.2 & 2.0 & 3.5 \\
\hline vII & 1.7 & 2.0 & 2.4 & 1.9 & 2.0 \\
\hline
\end{tabular}

* Fibrinolytic Protease activity expressed in $\mathrm{U} / \mathrm{ml}$. 
Table.4 Production of fibrinolytic protease in modified media

\begin{tabular}{|c|l|c|c|}
\hline $\begin{array}{c}\text { Medium } \\
\text { No. }\end{array}$ & \multicolumn{1}{|c|}{ Composition of media } & \multicolumn{1}{|c|}{ Enzyme yield (U/ml) } \\
\cline { 2 - 4 } I & $\begin{array}{l}\text { Fructose, } 1 \%, \text { fibrin, } 0.2 \% ; \text { peptone } 1 \% ; \\
\mathrm{MgSO}_{4}, 0.02 \%, \mathrm{KH}_{2} \mathrm{PO}_{4}, 0.2 \% ; \mathrm{NH}_{4} \mathrm{NO}_{3}, 0.5 \% \\
\text { and } \mathrm{CaCl}_{2} 0.04 \%\end{array}$ & $9.4 \pm 2.5$ & $13.1 \pm 3.6$ \\
\hline II & $\begin{array}{l}\text { Fructose, } 0.5 \% ; \text { fibrin, } 0.2 \%, \text { peptone } 1 \% ; \\
\mathrm{MgSO}_{4}, 0.02 \% ; \mathrm{KH}_{2} \mathrm{PO}_{4} ; 0.2 \%, \mathrm{NH}_{4} \mathrm{NO}_{3} ; 0.5 \% \\
\text { and } \mathrm{CaCl}_{2} 0.04 \%\end{array}$ & $8.4 \pm 2.8$ & $9.8 \pm 3.2$ \\
\hline III & $\begin{array}{l}\text { Fructose } 0.1 \%, \text { Yeast extract } 0.5 \%, \text { Tryptone } \\
0.5 \%\end{array}$ & $7.9 \pm 2.5$ & $8.9 \pm 3.2$ \\
\hline IV & Fructose $1 \%$, Yeast extract $0.5 \%$, Tryptone $0.5 \%$ & $8.0 \pm 2.0$ & $6.0 \pm 2.0$ \\
\hline
\end{tabular}

Maximum yield was obtained in medium IV. The composition of medium IV is Fructose, 1.0; fibrin, 0.2; peptone 1; $\mathrm{MgSO}_{4}, 0.02 \% ; \mathrm{KH}_{2} \mathrm{PO}_{4}, 0.2 \% ; \mathrm{NH}_{4} \mathrm{NO}_{3}, 0.5 \%$ and $\mathrm{CaCl}_{2} 0.04 \%$. This was designated as the basal medium and used for further studies.

Table.5 Fibrinolytic protease activity at different $\mathrm{pH}$ values

\begin{tabular}{|c|c|c|c|c|}
\hline \multirow{2}{*}{ Isolate } & \multicolumn{4}{|c|}{ Fibrinolytic protease activity (U/mI) } \\
\cline { 2 - 5 } & $\mathbf{p H ~ 4 . 0}$ & $\mathbf{p H ~ 7 . 0}$ & $\mathbf{p H ~ 8 . 0}$ & $\mathbf{p H ~ 1 0}$ \\
\hline KLG - 25 & $1.2 \pm 2.2$ & $8.7 \pm 1.4$ & $9.2 \pm 2.2$ & $1.3 \pm 2.4$ \\
\hline KLG -55 & $4.8 \pm 2.5$ & $10.6 \pm 1.8$ & $13.1 \pm 2.6$ & $3.5 \pm 2.0$ \\
\hline
\end{tabular}

Several effective thrombolytic agents have been identified and characterized from microorganisms, earthworms, plants, snake venoms, insects and leeches. Fibrinolytic proteases have wide applications in clinical, pharmaceutical, food, and bioremediation process. Among the various fibrinolytic proteases, bacterial extracellular fibrinolytic proteases are more attractive than those isolated from earthworms, plants, snake venoms, insects and leeches extracellular fibrinolytic proteases because of their high stability and unusual substrate specificity.

Different natural substrates collected from various places of Bangalore were screened for the isolation of potent fibrinolytic protease producing Bacillus cereus A total of 116 cultures were isolated from 10 samples. All the isolates were tested for their proteolytic activity on milk casein agar medium. After preliminary studies, isolates were further screened in two different media for their caseinolytic, gelatinolytic and fibrinolytic activities. Five promising isolates (KLG 15, KLG 25, KLG 35, KLG 45 and KLG 55), which showed good fibrinolytic activity were further screened for their enzymatic activities by shake flask method. Among these 5 isolates, isolate KLG 55 exhibited good fibrinolytic activity, while other showed poor to moderate activity. This was subjected to biochemical studies. A close study indicated that the isolate (KLG 55) was related to Bacillus cereus but different in some biochemical characteristics. In view of some significant differences from the reference culture, the isolate was considered to be the novel strains of Bacillus cereus.

Strain development for enzyme production has been an essential prerequisite for efficient production process. The main aim of strain improvement programme is to increase the product litres. The potential 
productivity of the organism is controlled by its genome and therefore the genome must be modified to increase the potential yield. The process of strain improvement involves genetic modification of the culture, followed by process optimization. Therefore, the strain of Bacillus cereus was subjected to strain improvement program with a view to obtain increased fibrinolytic protease production.

In conclusion, the isolate KLG 55 from the soil waste indicated the effective fibrinolytic activity at $\mathrm{pH} 8$, indicating the enzyme is an alkaline protease with comparatively good enzyme productivity $(13.1 \pm 2.6) \mathrm{U} / \mathrm{ml}$. Biochemcial studies clearly showed that the isolate KLG -55 is having similar characteristics as of Bacillus cereus. In view of some significant differences from the reference, the isolate was considered to be the novel strains of Bacillus cereus.

\section{References}

Astrup T and Mullertz S (1952). The fibrin plate method for estimating fibrinolytic activity. Arch Biochem. 40: 346-351.

Bode C, Runge MS, Schoenermark S, Eberle T, Newell JB, Kuebler W and Haber E (1990). Conjugation to antifibrin Fab' enhances fibrinolytic potency of single-chain urokinase plasminogen activator. Circulation. 81: 1974-1976.

Deshmukh AM (1997). Handbook of Media, Stains and Reagents in Microbiology. Pama Publication, Karad, India. 3-255.

Fujita M, Hong K, Ito Y, Fuji R, Kariya K and Nishimuro $\mathrm{S}$ (1995). Thrombolytic effect of nattokinase on a chemically induced thrombosis model in rat. BiolPharm Bull. 18(10): 1387-1391.

Gholamhossein E, Hossein S, Zahra Khosravi B and Soleiman A (2013).
Identification of a Bacterium Isolated From Soil of Ahvaz Contaminated by Oil and Determination of Its Protease Stability $\$ \mathrm{n}$ Organic Solvents. Jundishapur J Microbiol. 6: 106-111.

Greenberg DM (1957). Plant proteolytic enzymes. Methods in enzymology, ( $2^{\text {nd }}$ edition), Academic press INC. New York USA. 54-64.

Jeong YK, Park JU, Back H, Park $f H$, Kong IS, Kirn DW and Joo WH (2001). Purification and biochemical characterization of a fibrinolytic enzyme from Bacillus subtilis BK-17. World J Microbiol Biotechnol. 17: 8992.

Koide A, Suzuki S and Kobayashi S (1982). Preparation of polyethylene glycolmodified streptokina'se with disappearance of binding ability towards antiserum and retention of activity. FEBS Lett. 143: 73-76.

Kumaran S, palani P, Chellaram C, Premanand T and Kaviyarasan (2011). Screening of fibrinolytic protease from south Indian isolates of Ganodermalucidum. Int Jou Pharm Bio sci. 2: 419-431.

Leonardi A, Gubensek F and Krizaj I (2002). Purification and characterization of two hemorrhagic metalloproteinases from the venom of the long nosed viper, Vipera ammodytes. Toxicon. 40: 55-62.

Li S, He B, Bai Z and Ouyang P (2009). A novel organic solvent-stable alkaline protease from organic solvent-tolerant Bacillus licheniformis. J Mol Catal Enzym. 56: 85-88.

Lowry OH, Rosebrough NJ and Randall RJ (1951). Protein measurement with the Folin-phenol reagent. J Biol Chem. 193: 265-275.

McLaughlin B and Weiss JB (1996). Endothelial-cell-stimulating 
angiogenesis factor (ESAF) activates progelatinase A (72 $\mathrm{kDa}$ type IV collagenase), prostromelysin 1 and procollagenase and reactivates their complexes with tissue inhibitors of metalloproteinases. Biochem. J. 317: 739-745.

Pautov VD, Anufrieva EV, Ananeva TD, Saveleva NY, Taratina TM and Krakovyak MG (1990). Structural dynamic and functional properties of native and modified streptokinase. Mol Biol. 24: 35- 41.

Shanmugasundaram Senthil Balan, Rajendiran Nethaji, Sudalayandi Sankar and Singaram Jayalakshmi (2012). Production of gelatinase enzyme from Bacillus spp isolated from the sediment sample of Porto Novo Coastal sites. A J Trop Biomed. S1811-S1816.

Sumi H, Hamada H, Tsushima H, Mihara H and Muraki H (1987). A novel fibrinolytic enzyme (nattokinase) in the vegetable cheese Natto; a typical and popular soybean food in the Japanese diet. Experientia. 43(10): 1110-1111.
Torrens I, Ojalvo AG, Seralena A, Hayes O and Fuente J (1999). A mutant streptokinase lacking the C-terminal 42 amino acids is less immunogenic. Immunol Lett. 70: 213-218.

Tran LH and Nagano H (2002). Isolation and characteristics of Bacillus subtilis $\mathrm{CN} 2$ and its collaginase production. $\mathrm{J}$ of Food Science. 67: 1184-1187.

Voet D, Voet JG and Charlotte W (2008). Principles of Biochemistry, $3^{\text {rd }}$ edition, Wiley, New York. 87-95.

Williams ST and Cross T (1971). The Actinomycetes In: Methods in Microbiology, (ed. Booth, C) Academic Press, London. 4: 295.

Wong AH and Mine Y (2004). Novel fibrinolytic enzyme in fermented shrimp paste, a traditional Asian fermented seasoning. J Agric Food Chem. 52: 980-986.

Yoshinori M, Ado HO, Worig $\mathrm{K}$ and Jiang BO (2005). Fibrinolytic enzymes in Asian traditional fermented foods. Food Res Int. 38(3): 243-250.

Zerdani L, Paid M and Malki A (2004). Feather wastes digestion by new isolated strains Bacillus sp. In Morocco. Afr J Biotechnol. 3: 67-70.

\section{How to cite this article:}

Gopinath, S.M., and Lingappa, K. 2016. Isolation and Screening of Fibrinolytic Enzymes producing Bacterium Strain from Soil Waste. Int.J.Curr.Microbiol.App.Sci. 5(7): 969-976. doi: http://dx.doi.org/10.20546/ijcmas.2016.507.109 